\title{
Aims in teaching history and their epistemic correlates: A study of history teachers in ten countries
}

\section{Sakki, Inari Hannele}

2019

Sakki , I H \& Pirttilä-Backman , A-M 2019 , ' Aims in teaching history and their epistemic correlates: A study of history teachers in ten countries ', Pedagogy, Culture and Society , vol. 27 , no. 1 , pp. 65-85 . https://doi.org/10.1080/14681366.2019.1566166

http://hdl.handle.net/10138/309281

https://doi.org/10.1080/14681366.2019.1566166

unspecified

acceptedVersion

Downloaded from Helda, University of Helsinki institutional repository.

This is an electronic reprint of the original article.

This reprint may differ from the original in pagination and typographic detail.

Please cite the original version. 


\title{
Aims in teaching history and their epistemic correlates: A study of history teachers in ten countries
}

\begin{abstract}
Teaching history can mean balancing various tasks, from fostering national identity to enhancing critical thinking. In spite of the importance of the topic, there are few comparative studies of the aims of teaching history, even in Europe. Domain-specific epistemic beliefs are relevant for understanding the teaching and learning of history and the development of deliberative thought. We studied epistemic beliefs in the context of the general aims of teaching history. The respondents were 633 history teachers from ten countries. They rated the importance of 12 specified teaching aims, such as learning critical thinking, acquiring knowledge, developing patriotism, developing a personal identity. The epistemic beliefs were studied by asking how much the teachers agreed with four claims, such as historical truth is always tied to a perspective. Three meaningful clusters of teaching aims were identified. The clusters were named critical thinking and development; moral virtues and patriotism; and historical consciousness. History teachers in ten countries were classified within these clusters. There were significant differences among the clusters in the means of three epistemic beliefs. The results are discussed in the contexts of the countries studied.
\end{abstract}

Keywords: history epistemologies; aims of teaching history; critical thinking; patriotism; history teachers 
Teachers presumably serve as value transmitters in their societies, and for this reason, as argued by Schwartz and Bardi (2001), they are an interesting group to study. Along with values, they also teach domain-specific content knowledge by training students' historical thinking skills (e.g. Seixas and Morton 2013; Van Drie and Van Boxtel 2008). Moreover, their relatively similar functions throughout the world make comparisons between countries and regions feasible (Brauch 2017; Pirttilä-Backman, Menard, Verma, and Kassea 2017). Among teachers, those who teach history have a special position as socialization agents, because their subject deals with such questions as where we come from, who we are and where we are going. In European countries, which provide the context for the present study, this includes fostering students' competencies to orientate themselves historically as participating citizens in liberal-democratic societies in the present and in the future (Körber and Meyer-Hamme, 2015: Seixas and Morton, 2013).

Given the importance of what new generations learn, societies often make more or less detailed decisions about the aims, thematic areas and contents of the different disciplines taught in schools. Although the institutional aims of teaching history in different countries, i.e. as set forth in national curricula, provide an important context for our study, our focus is on individual teachers in ten countries and on the aims of teaching history as the teachers see them. We analyse these aims together with history epistemologies. These epistemologies are a sub-branch of research within the wider research area dealing with adolescents' and adults' epistemic beliefs and their justifications. This analysis, we argue, is important, firstly, because it enhances global understanding of how teachers perceive the aims of their teaching, and secondly, because it connects research on aims of teaching with the emerging field of history epistemologies and with epistemologies in a school context more generally. Before going into the details of the present study, we will first review previous research on the aims of teaching history and on history epistemologies.

\section{Aims of Teaching History}

The aims of teaching history are a debated topic. Different actors, including historians, politicians, educators and the public at large, argue about what should be taught about the past to younger generations. Some argue for a unified national story, while others support multiple perspectives; some prefer fact-based teaching, whereas others advocate an interpretative approach to history. In short, many scholars have acknowledged that there are competing objectives in the teaching of history in schools (Barton and Levstik, 2004; Wineburg, 2001). Carretero (2011) has redefined those objectives as either "romantic" or "enlightened" because their features and functions stem from their respective intellectual roots in Romanticism and the Enlightenment. In other words, these 
two different goals aim, on the one hand, to make students "love their country" and on the other hand, to make them "understand their past". Yet another central aim of teaching history - one that has attracted increasing interest among history educators - is often called historical thinking or historical reasoning, both terms emphasising the active role of students in learning and using history. Hence, the aim is to foster active critical thinking about history to empower students to participate in active democratic citizenship (e.g. Körber and Meyer-Hamme 2015; Seixas and Morton 2013; van Drie and van Boxtel 2008).

Nation-states have particular interest in education (Apple 2013). Many social and political scientists have recognized the links between mass education and identity building. Often statecontrolled history education is used as a major tool in the development and strengthening of national identity. For example, Hobsbawm (1990) has highlighted the crucial role of the school system in mediating narratives of a nation and in establishing national identification (see also László 2013). In a similar vein, Smith (1998) has pointed out that, by adopting an educator role, the state is capable of influencing a standardized, patriotic culture on a mass scale.

According to Carretero (2011), the nation-building goals of education were the most important in many countries until the 1960s, after which other goals became increasingly significant. However, even today state-controlled history education is a major tool in the development and strengthening of identity needs and political interests. This is especially clear in newly independent states undergoing nation-building processes. For instance, Korostelina's (2010, 2011) analysis of history education in Ukraine shows how the teaching of history is employed to establish national identity and influence the formation of borders between nations, particularly between Ukraine and Russia (Korostelina 2011). In Estonia in a post-Soviet context, Kello and Wagner (2014) studied how history teachers belonging either to the Estonian ethnic majority or to the Russian-speaking minority dealt with the society's and the state's expectations of instilling patriotism in their students. They found that, while ethnic Estonian history teachers conveyed a patriotic message in a largely implicit and casual way and based on intrinsic motivation rather than on external demand, Russian-speaking teachers experienced more control from different sides, particularly from the state, and tried to represent their students' loyalty to Estonia through careful and differentiated references to past Soviet realities. Perhaps even more strikingly, we are currently witnessing the ways in which the rise of nationalism and xenophobia in many European countries has found its way into the teaching of history. For instance, Hungary and Poland are living examples of countries where nationalist ideologies are instilled through history teaching practices, 
for example, through strict control over textbooks' content and style (Wagner, Kello, and Sakki 2018).

One can nevertheless argue that in recent decades, understandings of the objectives of teaching history have changed significantly. Different terms are used to describe these new aims. Alongside the emphasis on historical thinking and reasoning, developing and refining the historical consciousness of students (e.g. Seixas 2004) and emphasising the multi-perspectivity of education (e.g. Stradling 2003) have become more significant in history education. Historical consciousness can be defined as the understanding of the temporality of historical experience, in other words, in a way that past, present and future are thought to be connected (Ahonen 2005). According to Seixas (2012), historical consciousness can be addressed, among other ways, by teaching students to interpret primary source documents and reading them as products of the time of their creation, as well as by approaching contemporary historical accounts represented in films, textbooks and memoirs with a critical eye. Multi-perspectivity, as a core concept related to historical consciousness, can have various meanings, ranging from a teacher explaining different perspectives to students working with original sources (Stradling 2003). Multi-perspectivity is often understood as different nations' points of view. Yet it can also have a broader meaning, one that includes individual perspectives from various positions or life-worlds, such as those from different generations and professions. Although more research is needed, some empirical studies are addressing the usability of multiple perspectives (e.g. Wagner et al. 2018). For example, McCully (2012) studied the utility of enquiry-based, multi-perspective history teaching in the divided society of Northern Ireland and concluded that an enquiry approach, which places emphasis on the examination of evidence and the study of multiple perspectives, can have a positive impact on young people's thinking. The conclusion suggests that, by engaging with storytelling, history teaching may have the capacity to encourage young people to "care" for those from different backgrounds who have been victimized by conflict, and by examining such stories critically, we acquire a more nuanced understanding of the complex events of the past.

There is not much previous comparative research on history teachers' conceptions of the aims of teaching history. The previous comparative study on historical consciousness across Europe (Angvik and von Borries 1997) suggests that Europe can be divided into three blocks of countries in terms of their historical-political orientation: traditional communities in which religion, nation and one's own group are important, typically Mediterranean countries; modern communities with a high engagement with democracy, individuality and internationalism, typically Western and Northern European countries; and a mixture of modernism and traditionalism, which best describes post- 
communist countries. Our study endeavours to contribute to this under-examined field of research by asking if history teachers in ten European nations regard the aims of history teaching similarly or differently.

As we have discussed above, history education has many aims, but how can teachers balance these different demands? Kello and Masso (2012) analysed descriptions of teaching history in an Estonian teachers' newspaper. They found that, while private opinions revealed deep-rooted, traditional accounts based on knowledge-centred and ethnocentric representations, the official views took newer, more politically correct, skills-centred and multi-perspective approaches. This result indicates, among other things, that ideals and practices do not necessarily coincide in the teaching of history.

In recent studies, Wansink and his colleagues (2016, 2017) have examined Dutch history teachers' beliefs about the objectives of history education. Their qualitative analysis of Dutch teacher students' answers to open-ended questions brought to light six teaching objectives described as memorising, critical/explanatory, constructivist, perspective-taking, moral and collectiveidentity. These objectives were categorised under two epistemic perspectives on historical knowledge - as factual or as interpretative - the former relating to the romantic or identity function of history education and the latter relating to the enlightened, disciplinary goals of teaching history (cf. Carretero 2011). While collective identity and moral objectives were considered to represent historical knowledge as factual, the critical/explanatory, perspective-taking and constructivist objectives represented historical knowledge in the opposite way - as open and interpretative. The authors show, among other things, that all prospective history teachers they interviewed referred to the critical/explanatory objective of history teaching. This finding indicates that the commitment to develop children's active historical thinking skills is these teachers' main goal - at least on a theoretical level. However, their findings also show that most teachers mentioned both kinds of objectives. In other words, the teachers were able to change epistemic stances between factual and interpretative understandings of historical knowledge depending on the situation. In line with previous studies, the researchers argue that most history teachers are driven by different pedagogical, political and religious motives, which encourage them to combine epistemologically opposing objectives in real-life teaching situations (Wansink et al. 2017). Yet these recent studies addressing the link between teachers' epistemic beliefs and aims of history education have been not only scarce, but also limited to the analysis of a one-country context. The present study attempts to extend this line of research by exploring this relationship in ten European countries. First, however, we will discuss history epistemologies in the wider context of personal epistemologies. 


\section{History epistemologies}

Research on personal epistemologies originated in the seminal work of Willem Perry (1970/1999), in which he analysed how undergraduates at Harvard and Radcliffe responded to what Perry called relativism, which permeated the intellectual atmosphere of a pluralistic university. After having interviewed students at the end of each academic year, Perry concluded that the observed changes fell into a logical progression. Students' thinking moved from gradually opening up a basic dualism to seeing multiplicity, then an embrace of contextual relativism, and finally to making commitments based on uncertainty. Later, King and Kitchener (e.g. 1994) used Perry's model as the starting point for constructing an entire model and related method to study the development of epistemic beliefs and their justifications. In the first three stages, knowledge is understood as absolute. In stage one, what is seen is believed to be true. In stage two, it is understood that knowledge can be right or wrong but that nevertheless someone always knows the truth. Stage three is characterised by understanding that uncertainty can exist. However, if uncertainty exists, then it is considered temporary, and the thing will certainly be known in the future.

At stage four, knowledge is seen as inherently uncertain and uncertainty a permanent condition. The reasons for uncertainty are concrete. At the next stage, it is understood that all knowledge is contextual and that beliefs are justifiable only in a specific context. At the two highest stages, even though all knowledge is considered contextual, comparisons can be made between frames of reference, and some knowledge claims can be regarded as better than others. What distinguishes these last two stages is that, at the highest stage, knowledge is more clearly seen as a combination and an evaluation of standpoints and evidence. Furthermore, the perspective from which one is making the knowledge claims can be evaluated from other perspectives. In complex stage models such as that of King and Kitchener, it is assumed - and the empirical evidence supports the assumptions - that a person's epistemic thinking does not represent just one stage. It is usually possible to see elements of neighbouring stages in a person's argumentation.

The developmental models are the most well-known of the various kinds of epistemic belief models. Although these models differ in whether they talk about positions, stages or ways of knowing, what is common among them is that they include two major shifts or changes: one shift is to start to see plurality, while the other is to be able to commit oneself to deal with diversity. There is convincing support (Pirttilä-Backman 1993; Pirttilä-Backman \& Kajanne 2001) for the assumption that people argue epistemologically in quite similar ways about different kinds of 
topics. However, there is also increasing interest in domain-specific aspects of epistemic beliefs and thinking (e.g. Greene et al., 2016).

Research into domain-specific epistemic beliefs in history is a relatively new area. Presumably however, these beliefs are highly relevant in understanding the learning of history and the development of critical, deliberative thought. In their recent review of history-specific epistemic beliefs, VanSledright and Maggioni (2016) have remarked that, until recently, history education researchers have hardly studied epistemic beliefs about history and how these affect learning. The authors elaborate three factors that play a role in the history-related epistemic process: the object from the past in the form of accounts, the subject who imposes his/her subjective account on the objects to make them meaningful to her/himself, and the interpretative process. A possible fourth factor, socio-cultural context, could impose regulative ideals on the interpretative processes.

Until the present time, several studies have been carried out in which history epistemologies have been measured by means of questionnaires (see Stoel et al., 2017 for a summary of these studies). With the aim of addressing the problems encountered in previous empirical research on history epistemologies, Stoel and his coworkers based their own study on the conceptual distinction between naïve and nuanced epistemic understanding (e.g. Maggioni 2010; Maggione, VanSledright, and Alexander 2009). By naïve understanding they were referring to two kinds of ideas about history: on the one hand, objectivist ideas indicating knowledge that is fixed and singular, claims that are copies of the past or factual statements and knowledge that is embedded in the sources; on the other hand, subjectivist ideas point to knowledge that is uncertain and personal, claims that are opinions, and knowledge that is generated by the human mind. The nuanced understanding referred to criterialist ideas of history, meaning that knowledge is seen as being generated by human minds and is uncertain, yet is also bound by disciplinary methods, criteria of evidence and argument, and the notion that claims are judgements.

The sample by Stoel and his colleagues (2017) consisted of 922 students who were in their final year of upper secondary education. They also obtained ratings from seven experts in the field of history and historical philosophy. As had many researchers before them (e.g. Maggione et al. 2009), Stoel and colleagues found that building psychometrically acceptable scales to study developmentally-ordered epistemic beliefs presented considerable difficulty. The exploratory factor analysis produced five factors, four of which could be seen as either naïve or nuanced. The structural inconsistencies with the hypotheses, however, are highly interesting. For example, the items related to the subjectivity of historical knowledge produced diffuse results. Items loading high on this factor were originally designed to assess naïve beliefs (e.g. 'knowledge is opinion'), as well 
as more nuanced beliefs (e.g. 'historical knowledge is interpretation'). It turned out that the experts also had different views of these items. In their results a small factor focusing on historical method - reflecting the nuanced level - could be connected with the factors consisting of objectivity-related contents. This observation resonates well with the analysis of the highest stage of King and Kitchener's model constructed by Pirttilä-Backman (1993), which demonstrates that the role of commitment and seeing things as more certain are characteristic of the highest epistemic stage. The present study extends and deepens the literature dealing with the understudied field of epistemic beliefs in history by providing an analysis of epistemic beliefs in ten European countries. On the one hand, we draw from the previous work on personal epistemologies, which has established the developmental track from absolutism to plurality and commitment in diversity. On the other hand, we build on the basic distinction between naïve and nuanced history epistemologies. In the following section, we describe the contexts of the ten countries selected for the present study.

\section{Country contexts}

In this section we give examples of how the ten countries involved in our study officially deal with the aims of teaching history. We argue that this information provides a background to understand individual teachers' perceptions regarding the aims of teaching history. Also, in line with VanSledright and Maggioni (2016), we believe that the socio-cultural context plays a role in the history-related epistemic processes. The ten countries in our study are Austria, Belarus, Estonia, Finland, France, Germany, Italy, Israel, ${ }^{1}$ the Netherlands and Serbia. These countries differ in many ways, including their democratic performance (e.g. democracy index, 2018), and thus, their comparison might help us to understand how specific national pasts and current situations influence teachers ${ }^{\prime}$ beliefs regarding their teaching of history.

In Austria, the history curriculum emphasises the formation of an identity in a pluralistic society and the development of independent thinking skills as the key aims of history education. The curriculum acknowledges diversity in the classrooms and multi-perspectivity. Overcoming prejudice, racism and stereotypes is emphasised in the special aims of education. The formation of identity is built on acceptance and mutual respect instead of on national belonging. The curriculum also highlights intercultural and global learning as frameworks for history education. The curriculum is intended to develop a reflective and (self-) reflexive awareness of history and politics among the students and to raise awareness of the importance of democracy and human rights as

\footnotetext{
${ }^{1}$ Although Israel is a Middle Eastern country, for the sake of simplicity, in this study we include it as one of European countries when we refer to the countries of our study as a group.
} 
well as of European fundamental values (Lehrplan Geschichte und Sozialkunde/Politische Bildung 2015).

In a similar vein, in Finland the focus of the history curriculum is on the critical construction and evaluation of historical knowledge and on multi-perspectivity. The Finnish curriculum emphasises the global context and global values in teaching history; according to the most recent national curriculum (FNAE 2015, 170), teaching should emphasise human rights, equality, democracy and international co-operation as strategies to overcome challenges of today and of the future. Instead of local, national or European contexts, the curriculum holds that national history should be studied in a world history framework (FNAE 2015).

The German education system differs from the other countries in the present study, as each of the country's seventeen state governments (Länder) makes decisions about its own curriculum. However, a Conference of Ministers of Education (Kultusministerkonferenz, KMK) can formulate recommendations for a national approach to educational issues. The national standards relating to the objectives of teaching history contain nine general guidelines, including issues related to both multi-perspectivity and identity. However, the issues of identity in particular are treated with utmost care. The proposed standards themselves show no signs of a return to a national German history, but the topics related to Germany are placed within the general European and world context (Wilschut 2010).

History is a high-status subject in France. The French state has traditionally used the discipline of history to reinforce national pride and identity (Joutard 2000). However, since the beginning of the twenty-first century, more attention has been paid to the demands of multiple voices and diversity in the teaching of history. Humanistic values and democratic citizenship are the dominating principles in the current curriculum (Ministère de l'education nationale 2015).

In Italy, the history curriculum stresses the role of Italy as a country with an important historical heritage and a crucial role to play due to its geographical position on the Mediterranean Sea. On the other hand, the curriculum emphasises the multicultural classrooms of today and the importance of using history to understand present-day situations. The history curriculum attempts to enhance diversity and dialogue in multicultural and multiethnic classrooms and pays attention to the local, national and European dimensions of teaching (Cajani 2008).

Unlike the Austrian, Finnish and German history curricula, the current Dutch history curriculum, which stresses the interpretative nature of historical knowledge, emphasises the teaching of historical facts and an official national canon. This combination is described as an 
epistemic tension between learning historical facts and narratives, yet with a critical approach to these matters as constructions (Wansink et al. 2016). Thus, both critical thinking skills as well as identity-related aims are considered the key objectives in teaching history in the Dutch curriculum.

A similar dual pattern can be found in the Estonian history curriculum, which has undergone drastic changes in the 1990s since the collapse of the Soviet Union, a time when the teaching of history was expected to strengthen Estonian national identity. As Kello (2014) shows, although ideas of interpretative and multi-perspective history teaching have gradually become part of the history curriculum in the late 1990s, these ideas are not fully integrated into all documents and practices. In the current history curriculum, which is from the year 2010, an ethnocentric Estonian identity remains alongside the critical thinking skills as the key aims of teaching history.

Even more emphasis is placed on the national context in the Israeli history curriculum, which regards the development of a shared commitment to the State of Israel as the key aim of teaching history. The curriculum also emphasises dialogue and mutual respect between different sectors - the state, state-religious, and Arab and Druze sectors. Critical thinking skills appear as one objective among many and are not emphasised to the same extent as in some other countries in the present study (Israeli Ministry of Education I. Core History Curriculum 2014).

In Belarus, the history curriculum simultaneously emphasises the promotion of humanism and patriotism, the principles of civil society and the rule of law, and the cultural and historical heritage of the Belarusian people. As in Israel, the main framework for history education is Belarusian, although the uniqueness of other cultures and peoples is also recognised (Ministry of Education of the Republic of Belarus 2017).

Likewise in Serbia, history education has been state-centred and used to serve nationalist aims. In the twenty-first century this climate has been gradually changing and educational reforms are being implemented. These reforms stress, among other things, the questions of democratic participation and the international integration of Serbia (Mirkovic and Crawford 2003).

To sum up, our brief investigation of the history curricula in ten countries suggests that history as a school subject has different roles in different parts of Europe. In a similar vein as previously shown in our theoretical background, history curricula confirm the important role of nation-building aims in newly independent or post-Soviet countries, including such countries as Belarus, Serbia and Estonia. However, these traditional objectives of history also hold a rather central place in the curricula of France, the Netherlands and Israel. In all the curricula we investigated, democratic values and mutual respect were mentioned in a direct or indirect way, 
indicating the importance of democratic citizenship as the goal of history education all over Europe. Based on our overview, the changes of focus in history education in recent decades with an emphasis on underlying awareness of critical skills-orientated and perspective-taking teaching objectives are most strongly expressed in the history curricula of Germany, Finland and Austria. In addition, the increasing demands of including a diversity of perspectives in multicultural classrooms are shown, particularly in the Italian, French and Austrian history curricula.

Having outlined some underlying differences in the contexts of teaching history in ten European countries as well as the key theoretical concepts regarding the aims of history (nationbuilding, historical thinking, historical consciousness) and epistemic beliefs (naïve and nuanced beliefs), we now turn to the presentation of our research questions.

In this study we explore how history teachers from different countries perceive the teaching of their subject. Specifically, we are interested in how teachers in different European countries regard the aims of teaching history, how similar their views are, and whether their epistemic beliefs differ and are related to the aims of teaching their subject. In pursuit of these goals, we formulated three questions to guide our analyses.

1. What kind of clusters do aims of teaching history form?

2. How do teachers in ten countries differ in relation to the clusters of teaching aims?

3. How do teachers' history epistemologies differ in relation to the clusters of teaching aims?

\section{Methodology}

\section{Participants}

The present study is part of an e-questionnaire constructed jointly by an international research group studying sensitive issues in the teaching of history. The e-questionnaire consisted of several parts related to potentially sensitive issues in teaching history, the reasons for the sensitivity or lack of it, characteristics of the students and the teaching respondent, his/her views as a teacher and history teacher, and the respondent's characteristics. The questionnaire was translated from the working language of the group, English, into the majority language of each participating country. Colleagues who understood both languages carefully checked the translations.

The questionnaire was delivered to history teachers in various ways, depending on the possibilities available. For example, in Finland most school teachers' professional email addresses are available on the internet. The request to participate and a link to the questionnaire were sent 
individually by email to history teachers, starting with those from schools in the biggest cities and then proceeding to smaller towns. In some countries the questionnaires were delivered at events in which many history teachers were in attendance. It took around half an hour to fill in the questionnaire. The respondents were not compensated in any way for their participation. Table 1 shows the number of all respondents who answered the questionnaire, the total number of respondents to this study ${ }^{2}$ and their gender distribution by country.

Table 1. Gender distribution, the total number of respondents and the total number of respondents in the whole sample.

\begin{tabular}{llllll}
\hline Country & Men & Women & Sum & $\begin{array}{l}\text { Total in this } \\
\text { Study }\end{array}$ & $\begin{array}{l}\text { Total in the } \\
\text { whole } \\
\text { sample }\end{array}$ \\
\hline Austria & 26 & 19 & 45 & 45 & 49 \\
Belarus & 28 & 62 & 90 & 90 & 107 \\
Estonia & 12 & 21 & 33 & 33 & 37 \\
Finland & 41 & 38 & 79 & 80 & 93 \\
France & 35 & 41 & 76 & 76 & 78 \\
Germany & 7 & 9 & 16 & 18 & 20 \\
Holland & 47 & 35 & 82 & 82 & 82 \\
Israel & 46 & 37 & 83 & 83 & 98 \\
Italy & 5 & 40 & 45 & 47 & 59 \\
Serbia & 34 & 44 & 78 & 79 & 96 \\
Total & 281 & 346 & 627 & 633 & 719 \\
\hline
\end{tabular}

As Table 1 indicates, the gender distribution was slightly skewed towards females (55.1\%). The age and political orientation of the participants are presented by country in Table 2 .

\footnotetext{
${ }^{2}$ See below in section 'Results - Aims of history teaching in ten countries' for the exclusion criteria.
} 
Table 2. Distributions of the respondents' age (in years) and their political orientation $(1=$ extreme left, 8 = extreme right)

\begin{tabular}{lllllll}
\hline Country & Age & & \multicolumn{3}{l}{ Political positioning } \\
& M & SD & N & M & SD & N \\
\hline Austria & 40.0 & 10.7 & 45 & 3.6 & 1.1 & 39 \\
Belarus & 43.9 & 10.6 & 90 & 4.8 & 1.1 & 64 \\
Estonia & 49.2 & 11.6 & 33 & 4.9 & 1.1 & 29 \\
Finland & 47.8 & 9.2 & 80 & 4.6 & 1.6 & 76 \\
France & 44.6 & 11.3 & 73 & 3.4 & 1.4 & 74 \\
Germany & 38.4 & 11.0 & 16 & 3.7 & 1.0 & 15 \\
Holland & 38.2 & 10.1 & 82 & 3.7 & 1.1 & 82 \\
Israel & 42.2 & 10.0 & 79 & 3.3 & 1.8 & 81 \\
Italy & 50.0 & 8.7 & 44 & 5.8 & 1.4 & 42 \\
Serbia & 42.2 & 9.1 & 78 & 4.4 & 1.1 & 72 \\
\hline
\end{tabular}

As Table 2 suggests, the average age of our participants ranged from the youngest teachers in Holland ( $M=38.2$ years) to the oldest teachers in Italy $(\mathrm{M}=50$ years). The political orientation ranger from the most left-wing in Israel $(M=3.3)$ to the most right-wing in Italy $(M=5.8)$.

In Austria, Finland, France, Germany and Italy none of the teachers indicated that they belonged to an ethnic minority in the country. Proportionally, the largest portions of ethnic minority teachers were in the samples from Estonia (over one-third of the respondents) and Israel (over onefourth of the respondents).

\section{Measures}

The items used in this article deal with the aims of teaching history and epistemic beliefs.

Epistemic beliefs

The epistemic beliefs were studied by asking how much the teachers agreed or disagreed with the following claims, with answers given on a four-point scale $(1=$ absolutely disagree to $4=$ absolutely agree): 1) In history the facts speak for themselves and do not require interpretation. 2) Historical truth is essentially a matter of opinion or preference. 3) Historical truth is always tied to a perspective. 4) One interpretation can be more valid than another.

In a distinction made by Stoel and his colleagues (2017) the first two items represent naïveté while the last two items represent nuanced epistemic understanding. With the more detailed 
distinction made by King and Kitchener (1994), the first claim represents the second and third stages of epistemic beliefs, the second represents stage four, the third represents stage five and the fourth represents the two highest stages of the model.

Aims of teaching history

Previous research (e.g. Angvik and Borries 1997; Carretero 2011; Seixas and Morton 2013) inspired the formulation of the aims of teaching history. The list of aims was discussed by an international research group and complemented with local knowledge and experience from different country contexts. The importance of 12 specified aims and the possibility of suggesting and evaluating aims missing from the list were studied by asking the respondents to evaluate on a sixpoint scale $(0=$ not important at all, $5=$ very important) the following aims: Acquiring knowledge, Learning source criticism, Acquiring discussion and argumentation skills, Internalising democratic values, Learning from the past, Learning critical thinking, Developing a personal identity, Developing a national identity, Becoming better citizens, Developing patriotism, Learning to have fun with history, developing an interest in history and Developing moral virtues.

\section{Analyses}

K-means cluster analysis (SAS enterprise guide, version 6) was carried out for the 12 aims. Kmeans clustering solutions were run with different number of clusters (2-8), each with different initial solutions, which typically produces different final solutions. The criterion for the choice of the clustering solution was the interpretability of the solution as well as a sufficient size of respondents for each cluster. One-way analysis of variance (within subjects) was conducted for epistemic beliefs-related items to confirm the differences between epistemic beliefs in relation to the aims of history teaching.

\section{Results}

\section{Aims of Teaching History}

Teachers were asked to rate the importance of 12 aims of teaching history. As Table 3 indicates, teachers generally valued the presented aims highly, with the mean of all aims varying from 3.51 (in 
Holland) to 4.40 (in Belarus). In the entire sample, 'learning critical thinking' $(M=4.66)$, 'acquiring discussion and argumentation skills' $(\mathrm{M}=4.39)$ and 'learning source criticism' $(\mathrm{M}=4.37)$ were rated highest, while 'developing patriotism' $(\mathrm{M}=2.69)$, 'developing pupils' national identity' $(\mathrm{M}=$ $3.24)$ and 'developing moral virtues' $(M=3.70)$ were rated lowest. The standard deviations were smallest in the most highly-rated teaching aims and greatest in the lowest-rated aims. This suggests, among other things, that there were some differences among the ten countries regarding these latter aims. The between-country differences in the mean values of 12 aims of history teaching are presented in Table 3. 
Table 3. Mean values for the 12 aims of teaching history in ten countries $(N=633)$

\begin{tabular}{|c|c|c|c|c|c|c|c|c|c|c|c|}
\hline COUNTRIES & $\begin{array}{l}\text { Austria } \\
(\mathrm{N}=45)\end{array}$ & $\begin{array}{l}\text { Belarus } \\
(\mathrm{N}=90)\end{array}$ & $\begin{array}{l}\text { Estonia } \\
(\mathrm{N}=33)\end{array}$ & $\begin{array}{l}\text { Finland } \\
(\mathrm{N}=80)\end{array}$ & $\begin{array}{l}\text { France } \\
(\mathrm{N}=76)\end{array}$ & $\begin{array}{l}\text { Germany } \\
(\mathrm{N}=18)\end{array}$ & $\begin{array}{l}\text { Holland } \\
(\mathrm{N}=82)\end{array}$ & $\begin{array}{l}\text { Israel } \\
(\mathrm{N}=83)\end{array}$ & $\begin{array}{l}\text { Italy } \\
(\mathrm{N}=47)\end{array}$ & $\begin{array}{l}\text { Serbia } \\
(\mathrm{N}=79)\end{array}$ & $\begin{array}{l}\text { TOTAL } \\
(\mathrm{N}=633)\end{array}$ \\
\hline AIMS & & & & & & & & & & & $\mathrm{M}(\mathrm{SD})$ \\
\hline Acquiring knowledge & 3.87 & 4.24 & 3.85 & 4.15 & 4.38 & 4.00 & 4.05 & 4.20 & 4.57 & 4.29 & $4.19(.89)$ \\
\hline Learning source criticism & 4.51 & 3.62 & 4.21 & 4.49 & 4.78 & 4.44 & 4.46 & 4.41 & 4.60 & 4.43 & $4.37(.83)$ \\
\hline $\begin{array}{l}\text { Acquiring discussion and argumentation } \\
\text { skills }\end{array}$ & 4.64 & 4.54 & 4.70 & 4.25 & 4.54 & 4.61 & 3.99 & 4.31 & 4.64 & 4.25 & $4.39(.78)$ \\
\hline Internalising democratic values & 4.47 & 4.26 & 4.52 & 4.41 & 4.50 & 4.56 & 3.62 & 4.43 & 4.83 & 4.35 & $4.34(.90)$ \\
\hline Learning from the past & 3.91 & 4.49 & 4.00 & 4.04 & 3.93 & 3.78 & 3.65 & 3.88 & 4.34 & 4.09 & $4.03(1.04)$ \\
\hline Learning critical thinking & 4.78 & 4.48 & 4.73 & 4.84 & 4.68 & 4.72 & 4.67 & 4.55 & 4.79 & 4.61 & $4.66(.61)$ \\
\hline Developing a personal identity & 4.16 & 4.19 & 4.48 & 4.03 & 3.64 & 4.00 & 4.00 & 4.23 & 4.43 & 4.32 & $4.12(1.00)$ \\
\hline Developing a national identity & 2.49 & 4.39 & 3.94 & 3.11 & 2.62 & 2.06 & 2.12 & 3.57 & 3.26 & 3.91 & $3.24(1.51)$ \\
\hline Becoming better citizens & 3.04 & 4.78 & 4.30 & 3.79 & 3.71 & 2.89 & 3.27 & 4.12 & 4.66 & 4.32 & $3.97(1.19)$ \\
\hline Developing patriotism & 1.36 & 4.73 & 3.73 & 2.31 & 1.88 & 1.39 & 0.90 & 3.42 & 1.68 & 3.82 & $2.69(1.79)$ \\
\hline $\begin{array}{l}\text { Learning to have fun with history, } \\
\text { developing an interest in history }\end{array}$ & 4.31 & 4.43 & 3.85 & 4.45 & 3.43 & 3.89 & 4.33 & 4.36 & 4.17 & 3.80 & $4.14(1.02)$ \\
\hline Developing moral virtues & 3.27 & 4.64 & 4.48 & 3.30 & 2.45 & 3.39 & 3.06 & 4.48 & 3.21 & 4.38 & $3.70(1.39)$ \\
\hline TOTAL & $\begin{array}{l}3.73 \\
(.53)\end{array}$ & $\begin{array}{l}4.4 \\
(.58)\end{array}$ & $\begin{array}{l}4.23 \\
(.62)\end{array}$ & $\begin{array}{l}3.93 \\
(.51)\end{array}$ & $\begin{array}{l}3.71 \\
(.60)\end{array}$ & $\begin{array}{l}3.64 \\
(.53)\end{array}$ & $\begin{array}{l}3.51 \\
(.51)\end{array}$ & $\begin{array}{l}4.16 \\
(.59)\end{array}$ & $\begin{array}{l}4.10 \\
(.55)\end{array}$ & $\begin{array}{l}4.21 \\
(.48)\end{array}$ & \\
\hline
\end{tabular}


The aims of teaching history were analysed more closely using cluster analysis. Altogether 63 respondents were excluded from the analysis because they had given the highest number 5 for all 12 aims to be rated. Even after this procedure, the distributions of the responses were strongly skewed to the higher end of the scale. We therefore calculated a number for each respondent's aim which took into account the mean of all ratings for each respondent (for a similar procedure, see Verkasalo, Tuomivaara \& Lindeman 1996). The ratings used therefore indicated how much the rating of each aim differed from the person's average on the 12 aims. Furthermore, 23 respondents had one or more missing answers in the 12 aims, and they were also excluded from the analyses.

K-means cluster analysis (SAS enterprise guide, version 6) was carried out for the 12 aims. The analysis of a certain number of clusters was repeated with several random initial cluster centres, and the most meaningful solutions were further analysed and compared with the solutions for different numbers of clusters. A three-cluster solution provided the most meaningful solution to the data. The cluster means for each variable are presented in Table 4.

Table 4. Cluster means for the 12 aims of teaching history in a three-cluster solution $(N=633)$.

\begin{tabular}{|c|c|c|c|}
\hline & Cluster 1 & Cluster 2 & Cluster 3 \\
\hline Acquiring knowledge & .51 & -.09 & .44 \\
\hline $\begin{array}{l}\text { Learning source } \\
\text { criticism }\end{array}$ & 1.03 & -.24 & .88 \\
\hline $\begin{array}{l}\text { Acquiring discussion and } \\
\text { argumentation skills }\end{array}$ & .85 & .05 & .61 \\
\hline $\begin{array}{l}\text { Internalising democratic } \\
\text { values }\end{array}$ & .67 & .03 & .62 \\
\hline Learning from the past & .07 & -.09 & .24 \\
\hline $\begin{array}{l}\text { Learning critical } \\
\text { thinking }\end{array}$ & 1.29 & .22 & .91 \\
\hline $\begin{array}{l}\text { Developing a personal } \\
\text { identity }\end{array}$ & .54 & -.00 & -.00 \\
\hline $\begin{array}{l}\text { Developing national } \\
\text { identity }\end{array}$ & -2.15 & -.09 & -.61 \\
\hline Becoming better citizens & -.13 & .17 & -.23 \\
\hline Developing patriotism & -3.02 & -.09 & -1.84 \\
\hline $\begin{array}{l}\text { Learning to have fun } \\
\text { with history, } \\
\text { developing an interest in } \\
\text { history }\end{array}$ & .79 & -.05 & -.08 \\
\hline $\begin{array}{l}\text { Developing moral } \\
\text { virtues }\end{array}$ & -.46 & .18 & -.93 \\
\hline
\end{tabular}


In the first cluster, such teaching objectives as 'learning critical thinking', 'learning source criticism' and 'acquiring discussion and argumentation skills' had relatively high means. In the second cluster, such objectives as 'developing moral virtues' and 'becoming better citizens' had relatively high ratings. Also in this cluster, aims of 'developing national identity' and 'developing patriotism' were rated higher than in the other clusters, but it is noteworthy that ratings were still negative. In the third cluster, many of the aims were rated fairly similarly to some in the first cluster, for instance, 'learning critical thinking' and 'learning source criticism', but their ratings were not as high. Also, the goal of 'learning from the past' was rated relatively high in this third cluster. The results indicate that history teachers' aims could be divided into three clusters, which were named Cluster 1) critical thinking and development; Cluster 2) moral virtues and patriotism; and Cluster 3) historical consciousness.

\section{Aims of teaching history in ten countries}

We next analyse how history teachers in ten countries are located in the three cluster-model presented above. The respondents' country-wise division into different aims of teaching clusters is presented in Table 5. The respondents from different countries were unevenly distributed in the different clusters $(\mathrm{X} 2=325.74, \mathrm{df}=18, \mathrm{p}<.0001)$.

Table 5. Respondents' distribution by country in the three aims of teaching history clusters $(N=$ 633).

\begin{tabular}{lllll}
\hline & Cluster 1 & Cluster 2 & Cluster 3 & Total \\
\hline Austria & 21 & 6 & 18 & 45 \\
Belarus & 0 & 90 & 0 & 90 \\
Estonia & 1 & 26 & 6 & 33 \\
Finland & 23 & 27 & 30 & 80 \\
France & 20 & 13 & 43 & 76 \\
Germany & 11 & 3 & 4 & 18 \\
Holland & 49 & 6 & 27 & 82 \\
Israel & 14 & 52 & 17 & 83 \\
Italy & 16 & 11 & 20 & 47 \\
Serbia & 3 & 67 & 9 & 79 \\
Total & 158 & 301 & 174 & 633 \\
\hline
\end{tabular}

As Table 5 suggests, most history teachers in Austria, Germany and Holland considered the aims related to critical thinking and development (Cluster 1) as being the most important. Aims related to 
moral virtues and patriotism (Cluster 2) were valued most highly by most teachers from Belarus, Estonia, Israel and Serbia. History teachers in Finland, France and Italy appreciated most often those aims that we interpreted as belonging to historical consciousness (Cluster 3).

\section{Epistemic beliefs}

In all countries teachers agreed the least with the two least developed epistemic beliefs, with 'the facts speaking for themselves' being the option that was least agreed with in most countries. However, according to the models, the most developed belief - 'one interpretation being possibly better than another' - received the highest agreement only in a few countries. The most popular belief was that 'historical truth is always tied to a perspective'. The means of the different history epistemology items in the three aims of history teaching clusters are presented in Table 6.

Table 6. The means of the different history epistemological items in the three aims of history teaching clusters $(N=630-631)$.

\begin{tabular}{llll}
\hline & Cluster 1 & Cluster 2 & Cluster 3 \\
\hline $\begin{array}{l}\text { In history facts speak for } \\
\text { themselves and do not } \\
\text { require interpretation. }\end{array}$ & 1.49 & 1.91 & 1.46 \\
$\begin{array}{l}\text { Historical truth is } \\
\text { essentially a matter of } \\
\text { opinion or preference. }\end{array}$ & 2.22 & 2.16 & 2.09 \\
$\begin{array}{l}\text { Historical truth is always } \\
\text { tied to a perspective. }\end{array}$ & 3.29 & 2.71 & 3.09 \\
$\begin{array}{l}\text { One interpretation can be } \\
\text { more valid than another. }\end{array}$ & 3.13 & 2.62 & 2.91 \\
\hline
\end{tabular}

In a one-way ANOVA, the means of 'the facts do not need interpretation' item differed significantly $\mathrm{F}(2,627)=27,31, \mathrm{p}<.0001$ between the clusters. The mean was significantly higher at the level .05 (Tukey's test) in cluster 2 than in cluster 1 and 3 . The difference between clusters 1 and 3 was not significant.

The 'tied to perspective' item also differed between the clusters $F(2,628)=29.04$, $\mathrm{p}<.0001)$. The mean was significantly lower at the level .05 (Tukey's test) in cluster 2 than in clusters 1 and 3 . Again the means of clusters 1 and 3 did not differ significantly. 
Similar differences were observed in the 'One interpretation can be more valid' item $(\mathrm{F}(2,627)=19.90, \mathrm{p}<.0001)$. Also in this case, all the other pairwise comparisons were significant at the level .05 (Tukey's test) in cluster 2 than in clusters 1 and 3. The mean was lower in cluster 2 .

There was no statistically significant difference between the clusters in the 'truth is a matter of opinion' item.

To conclude, we decided to call the history epistemologies of the first and third clusters more nuanced and that of the second cluster more naïve.

\section{Discussion}

In this section we discuss the results of the above analysis and elaborate upon their implications for the existing knowledge of the aims and epistemic beliefs of teaching history.

We first asked how history teachers view the different aims of history teaching. Our results indicated that these aims formed three clusters, which we labelled 'critical thinking and development', 'moral virtues and patriotism' and 'historical consciousness'. It is noteworthy, however, that the two clusters 'critical thinking' and 'historical consciousness' consisted mostly of the same items, but these were not rated as highly in the latter cluster. This could mean that 'historical consciousness' is a milder version of the 'critical thinking' cluster, which is located between theoretically opposing objectives of 'critical thinking' and 'moral virtues and patriotism' (e.g. Carretero 2011). This cluster was named 'historical consciousness', because the only item that was rated higher in this cluster in comparison to the 'critical thinking' -cluster was the item 'understanding of the past' reflecting the idea of historical consciousness.

Our results indicate that 'learning critical thinking' was the most highly valued goal of teaching history across Europe. This result is in line with history educators' increasing focus on historical thinking, multi-perspectivity and historical consciousness. The focus on these aspects implies a desire to empower students to learn how to make critical interpretations based on the evidence of multiple sources, to contextualize a topic in a broader historical framework and to include the different perspectives of various people (e.g. Seixas 2004; van Drie and van Boxtel, 2008). On the other hand, the results also indicated that 'developing national identity' and 'developing patriotism' were aims that were considered as least important in most countries in our study. However, of these two aims, developing national identity was regarded as a more important goal of teaching history than developing patriotism in all ten countries except Belarus. This might indicate that the two concepts 'national identity' and 'patriotism' are imbued with different 
meanings. Although in theoretical literature (e.g. Bar-Tal 1997; Skitka 2005) 'patriotism' is defined as love for one's country and attachment to national values without any belief of superiority of one's nation, the teachers we surveyed may connect the idea of developing patriotism with outgroup antipathy. We argue that a somewhat negative echo of the nation-building aims among history teachers might be caused by changes in the societal atmosphere in Europe, namely the rise of nationalism and xenophobia, which has imbued these ideas with negative connotations.

The three-cluster model provided a structure that allowed us to identify patterns in the objectives of teaching history in different European countries. Thus, the second aim of this study was related to the differences and similarities among the ten selected countries. Our results indicated some interesting patterns. Most Austrian, German and Dutch teachers regarded aims related to 'critical thinking and development' as the most important. As discussed above, the history curricula in these countries also emphasised critical thinking, multi-perspectivity, a global framework and democratic values. An exception was the Dutch history curriculum, which along with skills-orientated aims, portrayed the teaching of history as a vehicle to teach facts and purvey a national canon. Thus, this finding suggests some contradiction between the official perception and the teachers' perceptions of the aims of teaching history. However, much in the same vein shown in our research, previous research has indicated that critical and explanatory aims were considered the main aims of teaching among Dutch history teachers (Wansink et al. 2016, 2017).

Conversely, compared to other countries, most Estonian, Israeli, Belarussian and Serbian teachers considered patriotic and moral aims of history education of higher importance, which is in line with the way official curricula in these countries described the objectives of the history discipline. This result is also consistent with previous studies indicating that patriotism and identityrelated aims are central in the new democracies of post-Communist societies (e.g. Kello and Wagner 2014; Korostelina 2010, 2011). In Israel, on the other hand, history education is used to promote the somewhat competing agendas of nation building and developing a shared democratic civil society (e.g. Al-Haj 2005).

Furthermore, most French, Italian and Finnish teachers considered the teaching aims related to historical consciousness as the most important. Finnish teachers' perceptions differed from Italian and French teachers, as the Finns were more divided as a group and many of them also considered moral virtues and patriotism-related motives to be important in teaching history. This finding is consistent with Ahonen's view (1998, 134-135), according to which Finland belongs to the value system of Western and Nordic countries, but at some points is closer to post-communist Estonia, particularly regarding the question of nationalism. 
Thus, teachers in our ten countries think only partly according to the three historicalpolitical orientations outlined in previous research (Angvik and von Borries 1997; Borries 2000). In this typology, Western countries (in our study France, Germany, the Netherlands, Austria), including Nordic countries (Finland), belong to modernist countries that value democracy and internationality; Mediterranean countries (in our study Italy, Israel) belong to traditionallyorientated countries that highlight customs, nationalism and communal values; and post-communist countries (in our study Belarus, Estonia, Serbia), which would make different choices between traditional and modernist values in order to make sense of the past and orientate themselves to the future. The most striking difference was that in the present study, aims related to moral virtues and patriotism were more often expressed by teachers from post-Soviet countries than by those from Mediterranean countries, which may reflect the new wave of hyper-nationalism gaining ground in post-Soviet states.

As a third objective of this study, we also wanted to analyse the epistemic beliefs of history teachers and their relationship to the aims of teaching history. Our results indicated that the participants agreed more with the nuanced epistemic beliefs than with the naïve beliefs, to use the terminology of Stoel and colleagues (2016). Our results also showed how teaching aims and epistemic beliefs were connected with one another. Seeing national identity and patriotism as more important aims than did other respondents was related to a higher agreement with the 'In history the facts speak for themselves and do not require interpretation' epistemic belief and less agreement with the beliefs 'Historical truth is always tied to a perspective' and 'One interpretation can be more valid than another'. The relationship was the reverse in clusters indicating higher appreciation of critical thinking and historical consciousness. We can interpret this finding to mean that there is a tendency to see national identity and patriotism in teaching history in absolutist terms, demanding less critical analysis and reflection. By contrast, when the aims emphasise the skills of more critical thinking, epistemic understanding is also more reflective. Our results demonstrate the suggestion of VanSledright and Maggioni (2016), namely that socio-cultural contexts impose regulative ideals on history-related epistemic processes.

Interestingly, the mean ratings of the item 'Historical truth is essentially a matter of opinion or preference', which reflects King and Kitchener's (1994) stage 4, did not differ among the three clusters. This resonates with the results of Stoel et al. (2016), indicating the difficulty of locating subjectivity on the epistemic scales. Further research is clearly needed to understand the meaning and role of subjectivity in history epistemologies. Also, the fact that the rating of the more nuanced 
items (items 3 and 4) did not follow exactly the expectations of developmental ordering indicates the challenges of measuring epistemic beliefs and the need for further research.

\section{Concluding remarks}

This study is not without its limitations. A significant limitation was the unbalanced data. The samples consisted of history teachers from ten countries. The size of the populations as well as the number of history teachers in each sample vary greatly. In some countries, the collected sample covered all history teachers in the country relatively well. This was the case, for example, in Finland, where we were able to recruit teachers from all parts of the country, from the large and middle-sized cities, from both genders and across the entire political spectrum of Finnish society. However, in some countries, especially in Germany, the sample is quite restricted compared to the history teacher population of the country as a whole. In sum, the results of the present study have limited generalizability and should be seen as exploratory.

Yet another limitation of the present study concerns the data collection procedures, which varied among the ten countries. In some countries teachers were approached by email; in other countries they were recruited through personal contacts or in teacher-dedicated events. Also, the translation of the original questionnaire is another potential limitation, but in the present study, we did not notice any problems regarding the translations of those items we used.

A further significant limitation of the present study concerns the instruments used to analyse epistemic beliefs and the aims of teaching history. These scales were not based on validated measures, as none of the existing instruments was regarded by our international research group as appropriate to cover the specific contexts of ten countries. Indeed, there is always a possibility that the way the items were formulated influenced the way they were answered. In this sense too, the results of the present study are of exploratory nature and need to be confirmed by future studies. The exploratory nature of the study and the interest in a wide variety of countries meant that it was not possible to focus on details or utilize such fine-grained distinctions as, for example, Lee and Shemilt (2004) have used for understanding historical accounts. In future studies more attention should be paid to country-specific specialties and cultural strengths and weaknesses in understanding historical knowledge (see e.g. Körber 2016; Seixas 2016).

As stated, the results of this study should be read with a critical eye. For example, labelling clusters is always an interpretative process and, as we have discussed above, it may sometimes 
make the differences between clusters look greater than they actually are (e.g. regarding Clusters 1 and 3).

Besides these limitations, we believe this research has implications for history education research, as comparative research on the aims of teaching history in different countries is nearly non-existent. This research also contributes to the current literature by providing new information about the interconnection between the history epistemologies and aims of teaching history.

We also believe this research has far-reaching implications for history education and can contribute to debates concerning history teaching objectives in different countries. The increasing diversity of multi-cultural classes in most European countries challenges the traditional objective of teaching history, which has been based on nation-building goals. The connection between naïve beliefs and nation-building aims that we were able to trace in this study can be considered an alarming finding, as it may reflect an idea of conveying to students a one-sided, black-and-white conception of history that may provide a potential vehicle for intolerance. Thus, the task for future research is to investigate this linkage further and find ways to provide tools for the promotion of mutual understanding and respect.

\section{Acknowledgements}

We thank Merja Halme for her assistance with the statistical analysis.

\section{References}

Ahonen, S. 1998. Historiaton sukupolvi? Historian vastaanotto ja historiallisen identiteetin rakentuminen 1990-luvun nuorison keskuudessa. [The no-history generation? The reception of history and construction of historical identity by the young people in the 1990s]. Helsinki: Suomen historiallinen seura.

Ahonen, S. 2005. "Historical consciousness: A viable paradigm for history education?" Journal of Curriculum Studies 37 (6): 697-707. 
Angvik, M. and B. von Borries, eds. 1997. Youth and history: A comparative European survey on historical consciousness and political attitudes among adolescents. Vol. A-B. Hamburg: KorberStiftung.

Al-Haj, M. 2005. "National ethos, multicultural education, and the new history textbooks in Israel." Curriculum Inquiry 35 (1): 47-71. doi: 10.1111/j.1467-873X.2005.00315.x

Apple, M. W. 2013. Knowledge, power, and education: The selected works of Michael W. Apple. New York: Routledge.

Bar-Tal, D. 1997. "The monopolization of patriotism". In Patriotism in the lives of individuals and nations, edited by D. Bar-Tal and E. Staub, 246-270. Chicago, ILL: Nelson-Hall Publishers.

Barton, K., and L. Levstik. 2004. Teaching History for the Common Good. Mahwah, NJ: Lawrence Erlbaum Associates.

Borries, B. von. 2000. "Methods and Aims of Teaching History in Europe: A Report on Youth and History." In Knowing, Teaching, and Learning History: National and International Perspectives, edited by P. N. Stearns, P. Seixas and S. Wineburg, 246-261. New York: New York University Press.

Brauch, N. 2017. "Bridging the Gap. Comparing History Curricula in History Teacher Education in Western Countries." In Palgrave Handbook of Research in Historical Culture and Education, edited by M. Carretero M., S. Berger and M. Grever. London: Palgrave Macmillan.

Cajani, L. 2008. Italy: General information about the education system and its legal framework. $\begin{array}{llll}\text { Accessed } & \text { May } & \text { 17, } & 2018 .\end{array}$ geschichte/itt/uploads/media/Italy_country_report_21.06.08.pdf 
Carretero, M. 2011. Constructing patriotism. Teaching of history and historical memory in globalized world. Charlotte, NC: IAP.

FNAE. 2015. Finnish National Agency for Education. Lukion opetussuunnitelman perusteet, määräykset ja ohjeet 2015:48 [National Core Curriculum for General Upper Secondary Education]. Helsinki: Finnish National Agency for Education.

Greene, J. A., W. A. Sandoval, and I. Bråten, eds. 2016. Handbook of Epistemic Cognition. New York: Routledge.

Hobsbawm, E. 1990. Nations and Nationalism since 1780: Programme, Myth, Reality. Cambridge: Cambridge University Press.

Israel Ministry of Education I. 2014. Core History Curriculum. http://cms.education.gov.il/EducationCMS/Units/Mazkirut_Pedagogit/History/TochnitLimudimvt/ mismach_liba_01.htm

Kello, K. 2014. "The functions and contexts of general education history teaching: social and professional representations in Estonia and Latvia." PhD. diss., University of Tartu.

Kello, K., and A. Masso. 2012. "The Spatial Foci of History Teaching: Individual Views of Estonian History Teachers." Spaces and Flows: An International Journal of Urban and ExtraUrban Studies 2 (4): 31-48.

Kello, K., and W. Wagner, W. 2014. "Intrinsic and Extrinsic Patriotism in School: Teaching History After Estonia's Critical Juncture.” International Journal of Intercultural Relations 10: 48-59. doi: 10.1016/j.ijintrel.2014.08.016. 
King, P. M., and K. S. Kitchener. 1994. Developing Reflective Judgment: Understanding and Promoting Intellectual Growth and Critical Thinking in Adolescents and Adults. Jossey-Bass Higher and Adult Education Series and Jossey-Bass Social and Behavioral Science Series. San Francisco: Jossey-Bass.

Korostelina, K. V. 2010. "War of Textbooks: History Education in Russia and Ukraine." Communist and Post-Communist Studies 43 (2): 129-137. doi: 10.1016/j.postcomstud.2010.03.004

Korostelina, K. V. 2011. "Shaping Unpredictable Past: National Identity and History Education in Ukraine.” National Identities 13 (1): 1-16. doi: 10.1080/14608944.2010.508817

Körber, A., 2016. “Translation and its discontents II: a German perspective.” Journal of Curriculum Studies 48 (4): 440-456.

Körber, A., and Meyer-Hamme, J. 2015. "Historical Thinking, Competencies and their Measurement: Challenges and Approaches." In: New Directions in Assessing Historical Thinking edited by K. Ercikan and P. Seixas, 89-101. New York: Routledge.

László, J. 2013. History tales and national identity: an introduction to narrative social psychology. London: Routledge.

Lee, P. and Shemilt, D. 2004. 'I just wish we could go back in the past and find out what really happened': progression in understanding about historical accounts. Teaching History: 25.

Lehrplan Geschichte und Sozialkunde/Politische Bildung, 2015. Accessed May 17, 2018. https://www.politik-lernen.at/dl/lompJKJKonMnkJqx4kJK/Lehrplanentwurf_GSK_PB_2015.pdf

Maggioni, L. 2000. "Studying epistemic cognition in the history classroom: Cases of teaching and learning to think historically." PhD diss. University of Maryland. 
Maggioni, L., VanSledright, B., and Alexander, P.A. 2009. "Walking on the borders: A measure of epistemic cognition in history." The Journal of Experimental Education 77 (3): 187-214. doi: 10.3200/JEXE.77.3.187-214

McCully, A. 2012. "History Teaching, Conflict and the Legacy of the Past." Education, Citizenship and Social Justice 7 (2): 145-159. doi: 10.1177/1746197912440854

Ministère de l'education nationale. 2015. “France decree $n^{\circ}$ 2015-372." Published in Official Journal April, 2, 2015: http://www.education.gouv.fr/pid285/bulletin_officiel.html?cid_bo=87834

Ministry of Education of the Republic of Belarus. 2017. "On teaching subjects 'World History' and 'History of Belarus' Instructive and methodological letter'.

Mirkovic, M., and K. Crawford. 2003. "Teaching History in Serbian and English Secondary Schools: a Cross-Cultural Analysis of Textbooks." International Journal of Historical Learning, Teaching and Research 3 (2): 91-106.

Perry Jr, W. G. [1970] 1999. Forms of Intellectual and Ethical Development in the College Years: A Scheme. Jossey-Bass Higher and Adult Education Series. San Francisco: Jossey-Bass.

Pirttilä-Backman, A. M. 1993. The social psychology of knowledge reassessed: Towards a new delineation of the field with empirical substantiation. Helsinki: Academia Scientiarum Fennica.

Pirttilä-Backman, A. M., and A. Kajanne. 2001. "The development of implicit epistemologies during early and middle adulthood." Journal of Adult Development 8 (2): 81-97. doi: 10.1023/A:102644180 
Pirttilä-Backman, A. M., R. L. Menard, J. Verma, and B. R. Kassea. 2017. "Social representations of trust among teachers and principals in Cameroonian, Indian, and Finnish schools." Journal of Social and Political Psychology 5(1): 29-57. doi: 10.5964/jspp.v5i1.206

Schwartz, S. H., and A. Bardi. 2001. "Value hierarchies across cultures: Taking a similarities perspective." Journal of cross-cultural Psychology $32 \quad$ (3): 268-290. doi: $10.1177 / 0022022101032003002$

Seixas, P. C., ed. 2004. Theorizing Historical Consciousness, Toronto: University of Toronto Press.

Seixas, P. C. 2012. "Progress, Presence and Historical Consciousness: Confronting Past, Present and Future in Postmodern Time." Paedagogica Historica 48 (6): 859-72. doi: $10.1080 / 00309230.2012 .709524$

Seixas, P. 2016. "Translation and its discontents: key concepts in English and German history education." Journal of Curriculum Studies 48 (4): 427-439.

Seixas, P., \& Morton, T. 2013. The Big Six Historical Thinking Concepts. Toronto: Nelson.

Skitka, L. J. 2005. "Patriotism or nationalism? Understanding post-September 11, 2001, flagdisplay behavior". Journal of Applied Social Psychology 35 (10): 1995-2011.

Smith, A. 2008. Nationalism and modernism. London: Routledge.

Stoel G., A. Logtenberg, B. Wansink, T. Huijgen, C. van Boxtel, and J. van Drie. 2017. "Measuring epistemological beliefs in history education: An exploration of naïve and nuanced beliefs." International Journal of Educational Research 83: 120-134. doi: 10.1016/j.ijer.2017.03.003

Stradling, R. 2003. Multiperspectivity in history teaching: a guide for teachers. Council of Europe. 
Van Drie, J., and Van Boxtel, C. 2008. "Historical Reasoning: Towards a Framework for Analyzing Students' Reasoning about the Past.” Educational Psychology Review 20: 87-110.

VanSledright and Maggioni 2016. "Epistemic cognition in history." In Handbook of epistemic cognition, edited by J.A. Greene, W.A. Sandoval and I Bråten, 128-146, New York, NY: Routledge.

Wagner, W., K. Kello, and I. Sakki. 2018. "Politics, Identity and Perspectives in History Textbooks." In: Representations of colonial pasts in (post)colonial presents - Historical and social psychological perspectives through textbook analysis, edited by K. van Nieuwenhuyse and J. P. Valentim. Information Age Publishing

Wansink, B. G. J., S. F. Akkerman, J. P P. Haenen, J. Vermunt, and T. Wubbels. 2017. "Epistemological tensions in prospective history teachers' beliefs about the objectives of secondary education.” Journal of Social Studies Research 41 (1): 11-24. doi: 10.1016/j.jssr.2015.10.003

Wansink, B. G. J., S. F. Akkerman, and T. Wubbels. 2016. "The Certainty Paradox of student history teachers - Balancing between historical facts and interpretation." Teaching and Teacher Education 56: 94-105. doi: 10.1016/j.tate.2016.02.005 